\title{
Medyada Yer Alan Beslenme ile İlgili Yayınların Diyabetli Bireylerin Beslenme Bilgi Düzeyleri ile İlişkisi
}

\section{The Relationship Between Nutritional Knowledge Levels of Patients with Diabetes and Nutrition-Related Publications in the Media}

\author{
Dilek Ongan $^{1}$, Berna Ağ $11^{1,}$ Gamze Yurtdaş ${ }^{1 *}$, Hüsnü Yılmaz ${ }^{2}$, Emre Ongan ${ }^{3}$, Devrim Dölek ${ }^{4}$ \\ ${ }^{1}$ İzmir Kâtip Çelebi Üniversitesi, Sağlık Bilimleri Fakültesi, Beslenme ve Diyetetik Bölümü, İzmir, Türkiye \\ ${ }^{2}$ İzmir Özel Can Hastanesi, Endokrinoloji ve Metabolizma Hastalıkları Birimi, İzmir, Türkiye \\ ${ }^{3}$ Çiğli Bölge Eğitim Hastanesi, Obezite ve Diyet Birimi, İzmir, Türkiye \\ ${ }^{4}$ Çiğli Bölge Eğitim Hastanesi, Endokrinoloji Polikliniği, İzmir, Türkiye
}

e-mail: dkatranci@gmail.com, agil.berna@gmail.com,gmzyurtdas@hotmail.com,drhuso@hotmail.com, emreongan@hotmail.com,devrimdolek@gmail.com

ORCID: 0000-0001-8948-9057

ORCID: 0000-0002-7008-4575

ORCID: 0000-0001-5410-7231

ORCID: 0000-0002-6297-4690

ORCID: 0000-0001-9571-3465

ORCID: 0000-0001-9571-3465

*Sorumlu yazar/ Corresponding Author: Gamze Yurtdaş

Gönderim Tarihi / Received: 25.07.2020

Kabul Tarihi / Accepted: 28.11.2020

DOI: $10.34087 /$ cbusbed. 773881

\section{$\ddot{\mathbf{O} z}$}

Giriş ve Amaç: Bu çalışma diyabetli bireylerin medya araçlarını kullanım durumlarını belirlemek, medyada yer alan beslenme ile ilgili yayınların diyabetli bireylerin beslenme bilgi düzeyleri ile ilişkisini değerlendirmek amacıyla yapılmıştır.

Gereç ve Yöntemler: Kesitsel tanımlayıcı tipte olan çalışma, İzmir-Çiğli Bölge Eğitim Hastanesi’nin Obezite ve Diyet Birimi'ne ve Endokrinoloji Polikliniği'ne başvuran 126 Tip 2 diyabetli hasta ile yürütülmüştür. Verilerin toplanmasında anket formu ve hastaların beslenme bilgi düzeyini ölçmek için "Diyabette Beslenme Tedavisi ile İlgili Bilgi Düzeyi Anketi” uygulanmıştır. Biyokimyasal bulgular hasta dosyalarından kaydedilmiştir.

Bulgular: Hastaların yaş ortalaması $56.59 \pm 10.90$ yıl olup, \%62.7'si kadındır. Hastaların \%89.6'sının her gün televizyon izlediği, \%45.2'sinin sosyal medyayı takip ettiği belirlenmiştir. Beslenmeyle ilgili en çok takip edilen konular; sağlıklı beslenme (\%55.7), beslenmeyle ilgili yeni yaklaşımlar (\%29.2), zayıflamadır (\%10.4). Hastaların \%21.4'ü medyada yer alan bilgilendirici içeriklerin besin seçimini etkilediğini belirtmiştir. İlkokul mezunu olan hastaların diyabette beslenme bilgi düzeyi en düşük iken, lise mezunu olanların en yüksektir $(p<0.001)$. Besin etiketi okuyan bireylerin beslenme bilgi düzeyleri, okumayanlara göre yüksek bulunmuştur ( $\mathrm{p}=0.016)$. Diyabette beslenme bilgi düzeyi ile medyayı/medyadaki beslenme içeriklerini takip etme durumu, medyadaki bilgilendirici içeriklerin besin seçimini etkileme durumu arasında ilişki saptanmamıştır ( $\mathrm{p}>0.05)$.

Sonuç: $\mathrm{Bu}$ çalışmada, diyabetli hastaların medyada yer alan beslenme içeriklerini takip etmelerinin hastaların beslenme bilgi düzeylerini etkilemediği bulunmuştur. Öte yandan, diyabette beslenme bilgi düzeyi eğitim seviyesi yüksek olan ve besin etiketi okuyan hastalarda daha yüksektir. Medya aracılığıyla edinilebilecek yanlış bilgilerden etkilenme olasılığı olan diyabet hastalarının beslenme bilgi düzeyinin besin etiketi okumayla artabileceği düşünülmüştür. Medyada, besin etiketi okumayı teşvik eden ve uzmanlar tarafından verilmiş doğru beslenme bilgileri içeren yayınların yer alması önerilmiştir.

Anahtar kelimeler: Besin etiketi okuma, Besin seçimi, Diyabette beslenme bilgisi, Medya, Tip 2 diyabet. 


\begin{abstract}
Objective: This study was carried out to determine use of mass media tools by individuals with diabetes, and to evaluate the relationship between nutritional knowledge levels and nutrition-related publications in media.

Materials and Methods This cross-sectional descriptive study was conducted with 126 Type 2 Diabetes Mellitus patients who applied to Obesity and Diet Unit and Endocrinology Outpatient Clinic of Çiğli Regional Training Hospital in İzmir. In data collection, questionnaire form and "Knowledge Level Questionnaire on Nutrition Therapy in Diabetes" were applied to measure nutritional knowledge level of patients. Biochemical findings were recorded from patient files.

Results: Mean age was $56.59 \pm 10.90$ years, $62.7 \%$ were female. It was determined that $89.6 \%$ of patients watched television every day, $45.2 \%$ followed social media. Topics about nutrition that patients followed most were healthy eating (55.7\%), new approaches in nutrition (29.2\%), weight loss (10.4\%). $21.4 \%$ of patients stated that informative contents in media affected their food choices. Primary school graduates had the lowest nutritional knowledge in diabetes, whereas high school graduates had the highest $(\mathrm{p}<0.001)$. Nutritional knowledge levels of individuals who read food labels were higher than those who did not $(\mathrm{p}=0.016)$. There was no relationship between nutritional knowledge levels of patients and state of following media and nutritional content in media, and the effect of informative contents in media ( $\mathrm{p}>0.05)$.

Conclusion: In this study, following nutritional contents in media did not affect nutritional knowledge levels of patients with diabetes. On the other hand, nutritional knowledge level was higher in patients with high level of education and who read food labels. In this group, where there is possibility of being affected by wrong information through media, it was considered that nutritional knowledge may be increased by reading food labels. It was suggested to include publications in media that encourage reading food labels and to contain accurate nutrition information provided by the experts.
\end{abstract}

Keywords: Food choice, Media, Nutritional information in diabetes, Reading food label, Type 2 diabetes.

\begin{abstract}
1. Giriş tüketimi teşvik edilmektedir [10]. Bu durum birçok
Diabetes Mellitus (DM), insülin hormonunun tamamen veya kısmen eksik salgılanması sonucunda meydana gelen, insülin direnci ve hiperglisemi ile karakterize kronik bir hastalıktır [1]. Tüm dünyada olduğu gibi ülkemizde de görülme sıklı̆̆ı hızla artmaktadır [2]. Hastalık oranlarının artışı yaşam biçimine bağlı faktörlerdeki değişikliklerle, özellikle düzensiz-dengesiz beslenme ile ilişkilendirilmektedir [3]. Hastalığa bağl1 olarak gelişen komplikasyonlar yüksek mortalite ve morbiditeye neden olmaktadır. Diyabet yönetiminde beslenme tedavisi anahtar rol oynamakta olup, diyabetin ve diyabetle ilişkili komplikasyonların önlenmesinde beslenme konusundaki artmış bilgi ve eğitimin olumlu etkilere sahip olabileceği bildirilmektedir $[4,5]$.

Günümüzde, insanlar televizyon, gazete-dergi, radyo, internet gibi farklı medya araçlarını kullanarak beslenme ve sağlık konularında bilgiye ulaşmaktadır [6]. Bu yolla bilgiye ulaşmanın birçok avantajı olmasına rağmen,

tüketimi teşvik edilmektedir [10]. Bu durum birçok
kronik hastalığa davetiye çıkarabileceği gibi DM gibi hastalığa özgü beslenme tedavisine ömür boyu dikkat edilmesi gereken hastalıklarda, beslenme tedavisine uyumu bozarak komplikasyonların daha erken dönemde gelişmesine, hızla ilerlemesine ve kötü hastalık seyrine neden olabilecek sonuçlar doğurabilir. Medyada yer alan yanlış yönlendirici bilgiler ve tedaviye uygun olmayan yiyecek-içeceklerin tanıtımları diyabetli bireylerin beslenme bilgilerini ve besin seçimlerini olumsuz etkileyebilir. Ancak, literatür incelendiğginde diyabette medyada yer alan beslenme ile ilgili bilgilerin diyabetli bireyleri nasıl etkilediğini değerlendiren yeterli veri bulunmamaktadır. Bu nedenle, bu çalışma diyabetli bireylerin medya araçlarını kullanım durumlarını belirlemek, medyada yer alan beslenme ile ilgili yayınları takip etmenin diyabetli bireylerin beslenme tedavisi hakkında bilgi düzeyleri ile ilişkisini değerlendirmek amacıyla planlanıp yürütülmüştür.
\end{abstract} ulaşılan bilgilerin doğruluğu ve güvenilirliği konusunda şüpheler oluşmaktadır. Bu şüphelerin oluşmasının nedeni medya araçları ile elde edilen bilgilerin genellikle bilimsel temelli olmaması ile açıklanmaktadır [7]. Özellikle medyada beslenme konusunda eğitimli olmayan bireylerin fikir beyan etmesi beslenmeyle ilgili bilgi kirliliğine sebep olmaktadır [7]. Pek çok insan sağlık veya beslenmeyle ilgili gelişmeleri ve bilgileri medyadan takip ederek çeşitli davranışlar ve tutumlar geliştirmektedir. $\mathrm{Bu}$ bağlamda medya araçlarından yayılan bilgiler bireylerin sağlığını etkileyebilmektedir [8]. Yapılan çalışmalarda özellikle çocukların ve kadınların besin tüketimlerinin/tercihlerinin reklamlardan ve diğer medya araçlarından olumsuz yönde etkilendiği gösterilmiştir [7, 9]. Radyo, televizyon ve internette sık tekrarlarla ve uzun süre tanıtımı yapılan sağlıksız besinler cazip hale getirilip, bu besinlerin

\section{Materyal ve Metot}

\subsection{Araştırmanın Yeri ve Zamanı} Eğitim Hastanesi'nin Obezite ve Diyet Birimi'ne ve Endokrinoloji Polikliniği'ne başvuran diyabetli hastalarla Ocak-Nisan 2019 tarihleri arasinda gerçekleştirilmiştir.

\subsection{Araştırmanın Tipi, Evren ve Örneklemi}

Kesitsel tipte tanımlayıcı olarak planlanan araştırmanın evrenini Çiğli Bölge Eğitim Hastanesi Endokrinoloji polikliniğinde takip edilen Tip 2 diyabetli yetişkin $(\geq 18$ yıl) hastalar oluşturmaktadır. Örneklem sayısının belirlenmesinde ki-kare testiyle güç analizi yapılmıştır ve $\% 90$ güçle örneklem sayıs1 117 diyabetli birey olarak belirlenmiştir. Çalışmanın sonucunda 126 Tip 2 diyabetli bireye ulaşılmıştır. Araştırmaya Tip 1 diyabetli, diğer
Araştırma İzmir ili sınırları içinde bulunan Çiğli Bölge 
spesifik diyabet türlerinden biri veya gestasyonel diyabeti olan bireyler dahil edilmemiştir.

\subsection{Verilerin Toplanmast}

Verilerin toplanmasında benzer çalışmalardan yararlanılarak, araştırmacılar tarafindan oluşturulan anket formu ve hasta dosyalarından kaydedilen biyokimyasal bulgular kullanılmıștır. Anket formu; bireylerin sosyo-demografik özellikleri, sağlık durumu ve hastalığa ilişkin bilgiler, besin satın alma davranışları, medya takibi, medyadaki yayınlar ile besin seçim arasındaki etkileşim durumu başlıklarını içeren 44 sorudan oluşmaktadır.

Diyabetli hastaların diyabette beslenme tedavisi ile ilgili bilgi düzeyini ölçmek amaciyla 20 sorudan oluşan, Beslenme ve Diyetetik Bölümü öğretim üyeleri tarafından hazırlanmış ve uygulanmış olan "Diyabette Beslenme Tedavisi ile İlgili Bilgi Düzeyi Anketi" kullanılmıştır [11]. Anket çoktan seçmeli sorulardan oluşmaktadır. Beslenme bilgi düzeyini belirlemek için sorulara doğru cevap verme durumu belirlenmiş ve doğru cevapların 1, yanlış cevapların 0 şeklinde puanlandırması yapılmıştır (doğru cevap sayısının ortalaması). Doğru cevap sayısı arttıkça bilgi düzeyinin arttığı kabul edilmiştir.

Hastalarla görüşme yapıldığı gün, hastalardan hekim ve diyetisyen kontrolü öncesi rutin alınan kan tahlili sonuçlarına göre açlık kan glukozu, HbAlc, total kolesterol, trigliserit, HDL-kolesterol ve LDL-kolesterol değerleri hasta dosyalarından kaydedilmiştir. Araştırma kapsamında katılımcılardan herhangi bir antropometrik ölçüm alınmamıştır.

\subsection{Araştırmanın Etik Yönü}

Araştırma için İzmir Kâtip Çelebi Üniversitesi Sosyal Araştırmalar Etik Kurulu'ndan 27.12.2018 tarihli etik onay, Çiğli Bölge Eğitim Hastanesi'nden kurum izni ve katılımcılardan bilgilendirilmiş yazılı onam alınmıştır. İmza atamayan/atmak istemeyen hastalardan bilgilendirilmiş sözlü onam alınmıştır. Anket formu hastanenin Diyabet Eğitim Odasında, çalışma grubundaki bir araştırmacı tarafından katılımcılarla yüz yüze görüşülerek doldurulmuştur.

\subsection{Verilerin Değerlendirilmesi}

Toplanan verilerin değerlendirilmesinde SPSS 22.0 istatistik paket programı kullanılmıştır. Veriler frekans (n), yüzde (\%), ortalama $(\bar{x})$, standart sapma (SS) ve medyan gibi tanımlayıcı istatistiklerle özetlenmiştir. Verilerin homojen dağılımına Shapiro-Wilk ve Kolmogrov-Smirnov testleriyle bakılmış, parametrik ve nonparametrik testler ile karşılaştırmalar yapılmıştır. Diyabette Beslenme Tedavisi ile ilgili Bilgi Düzeyi Anketi'nde veriler sıralı bilgi puanı olduğu için nonparametrik testler (Mann Whitney U, Kruskal Wallis) uygulanmıştır. Normal dağılmayan nicel değişkenlerin arasındaki ilişki Spearman korelasyon testi ile incelenmiştir. $\mathrm{p}<0.05$ değeri istatistiksel olarak önemli kabul edilmiştir.

\section{Bulgular ve Tartışma}

\subsection{Bulgular}

Çalışmaya katılan diyabetli hastaların \%37.3'ü erkek, $\% 62.7$ 'si kadın olup, yaş ortalaması $56.59 \pm 10.90$ yıldır. Hastaların \%57.9'u ilkokul mezunu, \%45.2'si ev hanımı, \%35.7'si emeklidir. Hastaların \%63.5'inin ailesinde diyabet öyküsü vardır. Hastaların cinsiyete göre eğitim durumları, meslekleri ve ailede diyabet varlığı arasında farklılık bulunmuştur $(\mathrm{p}<0.05)$. Kadın ve erkek hastaların açlık kan glukozu, HbA1c, total kolesterol ve LDLKolesterol değerleri benzer bulunmuştur ( $\mathrm{p}>0.05$ ) (Tablo 1).

Çalışmaya katılan diyabetlilerin, diyabet tanısı alma süresi $9.4 \pm 7.5$ yıldır. Diyabetli bireylerin yarısından fazlası (\%61.1) diyabet hastalığına yönelik beslenme eğitimi almıștır (eğitim almış olanların \%97.4'si diyetisyenden). Diyabetli bireylerin büyük kısmının (\%77.8) düzenli olarak diyabet diyeti uygulamadığ belirlenmiștir.

Hastaların besin seçerken en çok besinin sağllğa uygunluğuna/besleyici özelliğine $(\% 43.6)$ ve tazeliğine (\%23.8) dikkat ettiği saptanmıştır. Hastaların \%26.2'sinin besin etiketlerini her zaman, \%38.1'inin bazen okuduğu belirlenmiștir. Hastaların besin etiketlerini okurken sırasıyla; ürünün üretim-son kullanma tarihine (\%63.5), raf ömrüne (\%34.1), şeker içeriğine (\%16.6) ve içindekiler bölümüne (\%16.6), enerji ve besin ögesi değerlerine (\%15.8) dikkat ettiği saptanmıştır. Kadınların ve erkeklerin besin satın alma davranışları benzerdir (p>0.05) (Tablo 2).

Hastaların beslenmeyle ilgili medyayı takip etme durumları Tablo 3'te verilmiștir. Hastaların büyük bölümü (\%89.6) her gün televizyon izlediğini (izleme süresi: $4.1 \pm 2.5$ saat/gün), yaklaşık yarısı (\%45.2) sosyal medyayı takip ettiğini (takip süresi: $1.3 \pm 1.1$ saat/gün) belirtmiştir. Hastaların beslenmeyle ilgili en çok takip ettiği konular sırasıyla; sağlıklı beslenme (\%55.7), beslenmeyle ilgili yeni yaklaşımlar (\%29.2) ve zayıflamadır (\%10.4). Hastaların \%21.4'ü medyada yer alan bilgilendirici içeriklerin besin seçimini etkilediğini belirtmiştir. Hastaların medyadan etkilenip besin seçiminde değişiklik yaptığı başlıca ürünler; süt ve süt ürünleri (\%41.2), et grubu besinler (\%23.8), probiyotikler-prebiyotikler $(\% 19.0)$ ve diyet ürünleridir (\%18.2). Hastaların \%66.7'si medyanın beslenme ile ilgili bilgi düzeyini arttırdığını düşünmektedir. Hastaların çoğunluğu (\%61.5) medyadan aldıkları bilgileri diyetisyene/doktora sormamaktadır (Tablo 3).

Hastaların diyabette beslenme bilgi düzeylerinin bazı özellikleri açısından karşılaştırılması Tablo 4'te verilmiştir. Kadınlarla erkekler arasında diyabette beslenme bilgi düzeyi açısından istatistiksel olarak önemli fark bulunmamıştır ( $\mathrm{p}>0.05)$. Diyabette beslenme bilgi düzeyinin, eğitim durumu ilkokul düzeyinde olan hastalarda en düşük, lise mezunu olanlarda en yüksek olduğu saptanmıştır $(\mathrm{p}<0.001)$. Besin etiketi okuyan bireylerin diyabette beslenme bilgi düzeyleri, okumayanlara göre yüksek bulunmuştur $(\mathrm{p}=0.016)$. 
Tablo 1. Hastaların Genel Özellikleri

\begin{tabular}{|c|c|c|c|c|c|c|c|}
\hline 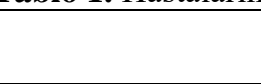 & \multicolumn{2}{|c|}{ Erkek (n:47) } & \multicolumn{2}{|c|}{ Kadın (n:79) } & \multicolumn{2}{|c|}{ Toplam (n:126) } & $\begin{array}{c}\text { İstatistiksel } \\
\text { Değerlendirme }\end{array}$ \\
\hline Yaş (yıl) & \multicolumn{2}{|c|}{$58.30 \pm 11.32$} & \multicolumn{2}{|c|}{$55.57 \pm 10.59$} & \multicolumn{2}{|c|}{$56.59 \pm 10.90$} & $\mathrm{p}=0.176$ \\
\hline & $\mathbf{n}$ & $\% *$ & $\mathrm{n}$ & $\% *$ & $\mathbf{n}$ & $\% * *$ & \\
\hline \multicolumn{8}{|l|}{ Eğitim Durumu } \\
\hline İlkokul & 20 & 27.4 & 53 & 72.6 & 73 & 57.9 & \multirow[t]{4}{*}{$p=0.003$} \\
\hline Ortaokul & 10 & 71.4 & 4 & 28.6 & 14 & 11.1 & \\
\hline Lise & 5 & 29.4 & 12 & 70.6 & 17 & 13.5 & \\
\hline Üniversite ve üzeri & 12 & 54.5 & 10 & 45.5 & 22 & 17.5 & \\
\hline \multicolumn{8}{|l|}{ Meslek } \\
\hline Kamu & 3 & 75.0 & 1 & 25.0 & 4 & 3.2 & \multirow{5}{*}{$\mathrm{p}<0.001$} \\
\hline Özel Sektör & 12 & 66.7 & 6 & 33.3 & 18 & 14.3 & \\
\hline Emekli & 30 & 66.7 & 15 & 33.3 & 45 & 35.7 & \\
\hline İşsiz & 2 & 100.0 & 0 & 0.0 & 2 & 1.6 & \\
\hline Ev Hanımı & 0 & 0.0 & 57 & 100.0 & 57 & 45.2 & \\
\hline \multicolumn{8}{|c|}{ Ailede Diyabet Varlığı } \\
\hline Var & 22 & 27.5 & 58 & 72.5 & 80 & 63.5 & \multirow[t]{2}{*}{$p=0.004$} \\
\hline Yok & 25 & 54.3 & 21 & 45.7 & 46 & 36.5 & \\
\hline \multicolumn{8}{|c|}{ Biyokimyasal Bulgular } \\
\hline Açlık kan şekeri & \multicolumn{2}{|c|}{$166.72 \pm 64.47$} & \multicolumn{2}{|c|}{$165.85 \pm 69.52$} & \multicolumn{2}{|c|}{$168.44 \pm 69.41$} & $\mathrm{p}=0.559$ \\
\hline HbA1c & \multicolumn{2}{|c|}{$8.19 \pm 2.04$} & \multicolumn{2}{|c|}{$7.91 \pm 1.99$} & \multicolumn{2}{|c|}{$8.07 \pm 2.04$} & $\mathrm{p}=0.511$ \\
\hline Trigliserit & \multicolumn{2}{|c|}{$163.48 \pm 81.92$} & \multicolumn{2}{|c|}{$160.26 \pm 76.30$} & \multicolumn{2}{|c|}{$170.97 \pm 105.58$} & $\mathrm{p}=0.619$ \\
\hline Total kolesterol & \multicolumn{2}{|c|}{$183.40 \pm 45.01$} & \multicolumn{2}{|c|}{$199.47 \pm 41.84$} & \multicolumn{2}{|c|}{$193.60 \pm 43.17$} & $\mathrm{p}=0.074$ \\
\hline LDL kolesterol & \multicolumn{2}{|c|}{$111.60 \pm 40.60$} & \multicolumn{2}{|c|}{$119.29 \pm 32.01$} & \multicolumn{2}{|c|}{$117.57 \pm 36.56$} & $\mathrm{p}=0.218$ \\
\hline HDL kolesterol & \multicolumn{2}{|c|}{$40.55 \pm 9.20$} & \multicolumn{2}{|c|}{$50.85 \pm 11.51$} & \multicolumn{2}{|c|}{$46.54 \pm 12.14$} & $\mathrm{p}<0.001$ \\
\hline
\end{tabular}

*Satır yüzdesi, **Sütun yüzdesi

Tablo 2. Hastaların Besin Satın Alma Davranışları

\begin{tabular}{|c|c|c|c|c|c|c|c|}
\hline \multirow[t]{2}{*}{ Besin Satın Alma Davranışları } & \multicolumn{2}{|c|}{ Erkek (n:47) } & \multicolumn{2}{|c|}{ Kadın (n:79) } & \multicolumn{2}{|c|}{ Toplam (n:126) } & \multirow{2}{*}{$\begin{array}{c}\text { İstatistiksel } \\
\text { Değerlendirme }\end{array}$} \\
\hline & $\mathbf{n}$ & $\% *$ & $\mathbf{n}$ & $\% *$ & $\mathbf{n}$ & $\% *$ & \\
\hline \multicolumn{8}{|c|}{$\begin{array}{l}\text { Diyabetli Bireylerin Besin Seçimini } \\
\text { Etkileyen Faktörler }\end{array}$} \\
\hline $\begin{array}{l}\text { Sağllğa Uygunluğu/ Besleyici } \\
\text { Özelliği }\end{array}$ & 21 & 44.6 & 34 & 43.0 & 55 & 43.6 & \multirow{5}{*}{$\mathrm{p}=0.581$} \\
\hline Tazeliği & 11 & 23.4 & 19 & 24.0 & 30 & 23.8 & \\
\hline Fiyat1 & 4 & 8.5 & 7 & 8.8 & 11 & 8.7 & \\
\hline Kişisel faktörler & 7 & 14.9 & 17 & 21.6 & 24 & 19.0 & \\
\hline $\begin{array}{l}\text { Diğer (ambalaj, marka, tüketici } \\
\text { tavsiyesi, kalite belgesi) }\end{array}$ & 4 & 8.5 & 2 & 2.6 & 6 & 4.7 & \\
\hline \multicolumn{8}{|l|}{ Besin Etiketi Okuma Durumu } \\
\hline Evet, her zaman & 14 & 29.8 & 19 & 24.1 & 33 & 26.2 & \multirow[t]{3}{*}{$\mathrm{p}=0.554$} \\
\hline Bazen & 15 & 31.9 & 33 & 41.8 & 48 & 38.1 & \\
\hline Hayır & 18 & 38.3 & 27 & 34.2 & 45 & 35.7 & \\
\hline \multicolumn{8}{|c|}{ Besin Etiketinde En Çok Dikkat Edilen Unsur* } \\
\hline Üretim-Son Kullanma Tarihi & 51 & 59.3 & 29 & 29.3 & 80 & 63.5 & \multirow{5}{*}{$\mathrm{p}=0.721$} \\
\hline Raf Ömrü & 14 & 16.3 & 29 & 29.3 & 43 & 34.1 & \\
\hline $\begin{array}{l}\text { Enerji ve Besin Ögesi } \\
\text { Değerleri }\end{array}$ & 8 & 9.3 & 12 & 12.1 & 20 & 15.8 & \\
\hline Şeker İçeriği & 6 & 6.9 & 15 & 15.2 & 21 & 16.6 & \\
\hline İçindekiler Bölümü & 7 & 8.1 & 14 & 14.1 & 21 & 16.6 & \\
\hline
\end{tabular}

*Sütun yüzdesi 
Tablo 3. Hastaların Beslenmeyle İlgili Medyadan Takip Ettikleri Başlıca Konuların Karşılaştırılması

\begin{tabular}{|c|c|c|c|c|c|c|c|}
\hline \multirow{2}{*}{$\begin{array}{l}\text { Medya Takibi ile ilgili } \\
\text { Bulgular }\end{array}$} & \multicolumn{2}{|c|}{ Erkek (n:47) } & \multicolumn{2}{|c|}{ Kadın (n:79) } & \multicolumn{2}{|c|}{ Toplam (n:126) } & \multirow{2}{*}{$\begin{array}{c}\text { İstatistiksel } \\
\text { Değerlendirme }\end{array}$} \\
\hline & $\mathbf{n}$ & $\%$ & $\mathbf{n}$ & $\%$ & $\mathbf{n}$ & $\%$ & \\
\hline \multicolumn{8}{|l|}{$\begin{array}{l}\text { Her Gün Takip Edilen } \\
\text { Medya Araçları* }\end{array}$} \\
\hline Televizyon & 42 & 89.3 & 71 & 89.8 & 113 & 89.6 & $\mathrm{p}=0.283$ \\
\hline Gazete & 11 & 23.4 & 5 & 6.3 & 16 & 12.6 & $\mathrm{p}<0.001$ \\
\hline Sosyal Medya & 15 & 31.9 & 42 & 53.1 & 57 & 45.2 & $\mathrm{p}=\mathbf{0 . 0 1 2}$ \\
\hline İnternet haberleri & 15 & 31.9 & 17 & 21.5 & 32 & 25.3 & $\mathrm{p}=0.625$ \\
\hline \multicolumn{8}{|c|}{ Beslenme İle İlgili Takip Edilen Konu* } \\
\hline Sağlıklı Beslenme & 23 & 60.5 & 36 & 52.9 & 59 & 55.7 & \multirow{6}{*}{$\mathrm{p}=0.147$} \\
\hline Zayıflama & 1 & 2.6 & 10 & 14.7 & 11 & 10.4 & \\
\hline $\begin{array}{l}\text { Beslenmeyle İlgili } \\
\text { Yeni Yaklaşımlar }\end{array}$ & 14 & 36.8 & 17 & 25.0 & 31 & 29.2 & \\
\hline Kanserden Korunma Yolları & 0 & 0.0 & 2 & 2.9 & 2 & 1.9 & \\
\hline Bitkisel İlaçlar & 0 & 0.0 & 1 & 1.5 & 1 & 0.9 & \\
\hline Hastalıklarda Beslenme & 0 & 0.0 & 2 & 2.9 & 2 & 1.9 & \\
\hline \multicolumn{8}{|c|}{$\begin{array}{l}\text { Medyada Yer Alan Bilgilendirici } \\
\text { İçeriklerin/Reklamların } \\
\text { Besin Seçimini Etkileme Durumu** }\end{array}$} \\
\hline Evet, her zaman & 9 & 19.2 & 18 & 22.8 & 27 & 21.4 & \multirow[t]{3}{*}{$\mathrm{p}=0.791$} \\
\hline Ara sira/Bazen & 19 & 40.4 & 34 & 43.0 & 53 & 42.1 & \\
\hline Hayır & 19 & 40.4 & 27 & 34.2 & 46 & 36.5 & \\
\hline \multicolumn{8}{|l|}{$\begin{array}{l}\text { Medyadan Etkilenip Besin } \\
\text { Seçiminde Değişiklik Yapılan } \\
\text { Başlıca Ürünler* }\end{array}$} \\
\hline Süt ve Süt Ürünleri & 20 & 42.5 & 32 & 40.5 & 52 & 41.2 & \multirow{5}{*}{$\mathrm{p}=0.875$} \\
\hline Et Grubu Besinler & 14 & 29.7 & 16 & 20.2 & 30 & 23.8 & \\
\hline Diyet Ürünler & 7 & 14.8 & 16 & 20.2 & 23 & 18.2 & \\
\hline Sıv1 Yağlar ve Margarinler & 9 & 19.1 & 13 & 16.4 & 22 & 17.4 & \\
\hline $\begin{array}{l}\text { Probiyotik ve Prebiyotik } \\
\text { Ürünler }\end{array}$ & 7 & 14.8 & 17 & 21.5 & 24 & 19.0 & \\
\hline \multicolumn{8}{|c|}{$\begin{array}{l}\text { Medyanın Beslenme ile ilgili } \\
\text { Bilgi Düzeyini Arttırdığı Düşüncesi** }\end{array}$} \\
\hline Evet & 27 & 57.4 & 57 & 72.2 & 84 & 66.7 & \multirow[t]{2}{*}{$\mathrm{p}=0.118$} \\
\hline Hayır & 20 & 42.6 & 22 & 27.8 & 42 & 33.3 & \\
\hline \multicolumn{8}{|c|}{$\begin{array}{l}\text { Medyadan Alınan Bilgilerin } \\
\text { Doktor/Diyetisyene Sorulma Sıklığı** }\end{array}$} \\
\hline Evet, her zaman & 4 & 10.2 & 16 & 22.9 & 20 & 18.3 & \multirow[t]{3}{*}{$\mathrm{p}=0.105$} \\
\hline Ara sira/Bazen & 6 & 15.4 & 16 & 22.9 & 22 & 20.2 & \\
\hline Hayır, hiçbir zaman & 29 & 74.4 & 38 & 54.3 & 67 & 61.5 & \\
\hline
\end{tabular}

*Birden fazla cevap verilmiştir. **Sütun yüzdesi 
Tablo 4. Hastaların Diyabette Beslenme Tedavisi ile ilgili Bilgi Düzeylerinin Bazı Özellikleri Açısından Karşılaştırılması

\begin{tabular}{|c|c|c|}
\hline Değişkenler & $\begin{array}{c}\text { Diyabette Beslenme Bilgi Düzeyi } \\
\text { (ort } \pm \text { SS) (medyan) }\end{array}$ & İstatistiksel Değerlendirme* \\
\hline \multicolumn{3}{|l|}{ Cinsiyet } \\
\hline Erkek (n:47) & $13.44 \pm 2.36(13.00)$ & \multirow[t]{2}{*}{$\mathrm{U}=1791.5, \mathrm{p}=0.741$} \\
\hline Kadın (n:79) & $13.50 \pm 2.50(14.00)$ & \\
\hline Toplam (n:126) & \multicolumn{2}{|c|}{$13.48 \pm 2.44(13.00, \min =7.00-\operatorname{maks}=19)$} \\
\hline \multicolumn{3}{|l|}{ Eğitim durumu } \\
\hline İlkokul (n:73) & $12.65 \pm 2.34(13.00)$ & \multirow{4}{*}{$\mathrm{p}<0.001$} \\
\hline Ortaokul (n:14) & $14.07 \pm 2.26(14.00)$ & \\
\hline Lise (n:17) & $15.29 \pm 1.86(16.00)$ & \\
\hline Üniversite ve üzeri (n:22) & $14.45 \pm 2.15(14.50)$ & \\
\hline \multicolumn{3}{|l|}{ Ailede diyabet varlığı } \\
\hline $\operatorname{Var}(\mathrm{n}: 80)$ & $13.65 \pm 2.55(14.00)$ & \multirow[t]{2}{*}{$\mathrm{U}=1597.50, p=0.216$} \\
\hline Yok (n:46) & $13.19 \pm 2.22(13.00)$ & \\
\hline \multicolumn{3}{|c|}{ Medyayı takip etme durumu } \\
\hline Evet (n:106) & $13.47 \pm 2.45(13.00)$ & \multirow[t]{2}{*}{$\mathrm{U}=1055.50, \mathrm{p}=0.976$} \\
\hline Hayır (n:20) & $13.55 \pm 2.43(13.50)$ & \\
\hline \multicolumn{3}{|c|}{$\begin{array}{l}\text { Medyada yer alan bilgilendirici } \\
\text { içeriklerin/reklamların besin } \\
\text { seçimini etkileme durumu }\end{array}$} \\
\hline Evet (n:27) & $13.48 \pm 2.48(14.00)$ & \multirow[t]{3}{*}{$\mathrm{p}=0.974$} \\
\hline Bazen (n:53) & $13.41 \pm 2.36(13.00)$ & \\
\hline Hayır (n:46) & $13.56 \pm 2.55(13.50)$ & \\
\hline \multicolumn{3}{|c|}{ Besin etiketi okuma durumu } \\
\hline Evet (n:81) & $13.88 \pm 2.49(14.00)$ & \multirow[t]{2}{*}{$\mathrm{U}=1353.50, \mathbf{p}=\mathbf{0 . 0 1 6}$} \\
\hline Hayır (n:45) & $12.75 \pm 2.18(13.00)$ & \\
\hline \multicolumn{3}{|c|}{$\begin{array}{l}\text { Medyada yer alan beslenme } \\
\text { ile ilgili içerikleri } \\
\text { takip etme durumu }\end{array}$} \\
\hline Evet (n:62) & $13.40 \pm 2.51(13.00)$ & \multirow[t]{3}{*}{$\mathrm{p}=0.977$} \\
\hline Bazen (n:44) & $13.56 \pm 2.39(13.50)$ & \\
\hline Hayır (n:20) & $13.55 \pm 2.43(13.50)$ & \\
\hline
\end{tabular}

*Diyabette Beslenme Bilgi Düzeyi testinde veriler sıralı bilgi puanı olduğu için nonparametrik testler (Mann Whitney U, Kruskal Wallis) uygulanmıştır.

Hastaların diyabette beslenme bilgi düzeylerinin ailede diyabet olan ve olmayan, medyayı takip eden ve etmeyen, medyada yer alan bilgilendirici içeriklerin besin seçimini etkilediğini düşünen ve düşünmeyen ve medyadaki beslenme içeriklerini takip eden ve etmeyen hastalar arasında farklı olmadı $\breve{g}$ belirlenmiștir ( $\mathrm{p}>0.05$ ) (Tablo 4). Diyabette beslenme tedavisi ile ilgili bilgi düzeyi ile diyabet yaşı, açlık kan glukozu, HbAlc, trigliserit, total kolesterol, HDL-K, LDL-K değerleri (Tablo 1) arasında ilişki saptanmamıştır (Tablo 5).

Tablo 5. Hastaların Bazı Biyokimyasal Bulgularının Diyabette Beslenme ile ilgili Bilgi Düzeyi ile İlişkisi

\begin{tabular}{|l|c|c|}
\hline Değişkenler & r & p \\
\hline Diyabet yaşı (yıl) & -0.078 & 0.383 \\
\hline Açlık kan glukozu (mg/dl) & -0.013 & 0.884 \\
\hline HbA1c $(\%)$ & -0.024 & 0.804 \\
\hline Trigliserit $(\mathrm{mg} / \mathrm{dl})$ & 0.011 & 0.909 \\
\hline Total kolesterol $(\mathrm{mg} / \mathrm{dl})$ & -0.019 & 0.841 \\
\hline LDL kolesterol $(\mathrm{mg} / \mathrm{dl})$ & 0.021 & 0.831 \\
\hline HDL kolesterol $(\mathrm{mg} / \mathrm{dl})$ & -0.065 & 0.503 \\
\hline
\end{tabular}




\subsection{Tartışma}

Beslenme tedavisi, Tip 2 DM tedavisinin temel bileşenlerinden biri olup, DM kontrolünün yanında sağlıklı yaşamın da önemli bir unsurudur [5, 12]. Medya araçları besin, sağlıklı beslenme ve diyet ile ilgili bilgileri topluma ileten en yaygın beslenme eğitim aracı olarak değerlendirilmektedir [6, 7]. Bu çalışma medyada yer alan beslenme ile ilgili yayınların takibinin, Tip 2 diyabetli bireylerin beslenme tedavisiyle ilgili bilgi düzeyleri ile ilişkisini değerlendirmek amacıyla yapılmıştır. Son yıllarda ev dışında yeme yeme oranının artması, ucuz menüler sunan restoranların çoğalması, marketlerde işlenmiş besinlerin artışı; bireylerin sağlıklı besin seçimini zorlaştırmaktadır. Bu çalışmada hastaların besin seçerken en çok besinin sağlığa uygunluğu/besleyici özelliği ve tazeliğine dikkat ettiği saptanmıştır (Tablo 2). Üniversite öğrencileri ile yapılan bir çalışmada öğrencilerin besin satın almalarında marka faktörünün daha etkili olduğu saptanmıştır [13]. Özellikle düşük gelirli bireylerde besin seçimini; besinin ulaşılabilirliği ve fiyatının etkilediği, besin değerinin daha az etkili olduğu bulunmuştur [7, 14]. Bu çalışmada, yaklaşık 10 yıldır diyabetli olan hastaların, bu süreçte diyabetin beslenme tedavisini öğrenmeleri ve sağlıklı beslenme bilinci kazanmaları ile besin seçerken sağlığa uygunluğu ve besleyici değeri öncelikle dikkate aldıkları düşünülmektedir.

Besin etiketleri, besinlerin laboratuvar analizi ile saptanmış besin ögelerinin miktarını ve bu miktarla tüketicinin günlük alması gereken besin ögelerinin ne kadarının karşılandığını göstermektedir [15]. Bu çalışmada, hastaların yarıdan fazlasının besin etiketlerini okuduğu (toplam \%64.3) belirlenmiştir (Tablo 2). Tüketicilerin etiket okuma durumlarını değerlendiren bir çalışmada, bireylerin \%20'sinden fazlasının besin etiketlerini "nadiren" okudukları ya da "hiçbir zaman" okumadıkları saptanmıştır [16]. Meksika Ulusal Sağlık Araştırması'nda diyabetli hastaların, diğer sağlıklı bireylere göre daha düşük oranda besin etiketi okuduğu rapor edilmiştir [17]. Besin etiketi okuma alışkanlığ1 oranı yüksek olmayan toplumlarda bu sonuç beklenmekle birlikte, DM hastalarının bireyselleştirilmiş tıbbi beslenme tedavisini takip etmeleri zorunluluğ nedeniyle besin etiketi okumaya daha fazla özen göstermeleri gerekmektedir.

Hastalar, besin etiketlerini okurken en çok üretim-son kullanma tarihine, raf ömrüne, enerji ve besin ögesi değerlerine, şeker içeriğine ve içindekiler bölümüne dikkat etmektedir. Tüketicilerin "besin etiketleme" konusundaki tutum ve davranışlarını değerlendiren bir çalışmada, besin etiket bilgileri içinde en fazla okunan 5 bilginin son kullanma tarihi, üretim tarihi, raf ömrü, ürünün adı-markası ve içindekiler olduğu saptanmıştır [18]. Gözener ve arkadaşları [19] öğrencilerin satın aldıkları gıda ambalajı üzerindeki etiketlerde \%90.38'nin son kullanma tarihine, \%45.67'sinin üretim tarihine, \%45.19'unun içindekiler kısmına, \%12.98'inin logolara ve \%9.13'ünün ağırlığına dikkat ettiklerini belirlemişlerdir. Kan glikozu üzerinde karbonhidratların diğer besin ögelerinden daha büyük etkiye sahip olması yönüyle şeker içeriğinin ve beslenme konusunda bilgilendirilmiş olmaları nedeniyle enerji ve diğer besin ögelerinin; diyabetli bireylerin sağlıklı tüketicilere göre besin etiketinde daha çok önemsedikleri bilgiler olduğu düşünülmektedir. Ayrıca, diyabet gibi beslenme ile ilişkili kronik hastalığı olan bireyler spesifik besin ögeleri ve enerji alım düzeyleri belirlenmiş diyet tüketmeleri nedeniyle besin etiketlerindeki bu bilgilere dikkat ediyor olabilirler.

Günümüzde teknolojik gelişmelere bağlı olarak yaygınlaşan ve çeşitliliği artan medya araçları vasıtasıyla aynı anda geniş kitlelere ulaşılabilmektedir [7]. Çalışmaya katılan hastaların medyayı takip etme araçları değerlendirildiğinde; hastaların büyük çoğunluğunun her gün televizyon izlediği, yaklaşık yarısının sosyal medyayı takip ettiği belirlenmiştir. Hastaların medyada beslenme ile ilgili olarak en çok "sağlıklı beslenme", "beslenme ile ilgili yeni yaklaşımlar" ve "zayıflama" konularını takip ettiği saptanmıştır (Tablo 3). Benzer şekilde, medyanın kadınların beslenme alışkanlıkları, besin seçimi ve tüketimi üzerindeki etkilerini değerlendiren bir çalışmada, kadınların \%81.7'sinin televizyonu, \%74.0'ünün interneti takip ettiği saptanmıştır. Kadınların medyada başlıca sağlıklı beslenme, özel durumlarda beslenme ve zayıflama konularını takip ettiği bildirilmiştir [7]. Aynı şekilde başka bir çalışmada, öğrencilerin \%62.0'sinin medya araçlarında sağlıklı beslenme; \%47.4'ünün ise zayıflama konusuna ilgi duydukları saptanmıştır [20]. Bir başka çalışmada, diyabet hastalarının, hastalık hakkında bilgilendirilmesinde eğitim aracı olarak sosyal ağ sistemi olan facebook platformununun kullanımının etkili bir araç olduğu bildirilmiştir [21]. Kitle iletişim araçlarının beslenme ile ilgili içerikleri her geçen gün artmaktadır, ancak bu yolla verilecek beslenme ve sağlık mesajlarının halkı ve özellikle diyabet gibi kronik hastalığ 1 olan bireyleri olumlu yönde etkilemesi için bilimsel bilgiler ışığında beslenme ve diyetetik uzmanları tarafından hazırlanmış içerikler olması gerekmektedir.

Medya araçları ile halka sunulan beslenme ile ilgili yayınların bireylerin besin tüketim tercihlerini ve dolaylı olarak beslenme alışkanlıklarını etkilediği çalışmalarda gösterilmiştir [22-24]. Bu çalışmada hastaların \%21.4'ü medyada yer alan bilgilendirici içeriklerin besin seçimini etkilediğini belirtirken, bireylerin medyadan etkilenerek besin seçiminde değişiklik yaptıkları başlıca ürünler; süt ve süt ürünleri, et grubu besinler, diyet ürünleri, yağlar, probiyotik-prebiyotiklerdir (Tablo 3). Mankan ve İçer'in [25] beslenme-gastronomi ile ilgili haberlerin ve köşe yazılarının üniversite öğrencilerinin beslenme alışkanlıklarına etkisini değerlendirdikleri bir çalışmada, öğrencilerin \%30.8'inin beslenmeyle ilgili reklamlardan bazen etkilenerek beslenme alışkanlıklarını değiştirdikleri bildirilmiştir. Aynı çalışmada, öğrencilerin haberlerden etkilenip tercihlerinde değişiklik yaptığ başlıca besinlerin et grubu besinler, süt ve ürünleri, probiyotik-prebiyotik ürünler, diyet ürünler, bitki çayları ve çaylar, fast food ürünler olduğu belirlenmiştir [25]. Yapılan bir başka çalışmada kadınların \%92.1'inin sağlık ve beslenme konusunda 
medyada çıkan yazılardan etkilenerek beslenme alışkanlıklarını değiştirdikleri saptanmıştır [26]. Diğer tüketici çalışmalarıyla uyumlu olarak, bu çalışmaya katılan bireylerin de besin seçimini medyadan etkilenerek değiştirdikleri belirlenmiştir. Besin tercihlerini medyanın yönlendirme potansiyeli olduğu bu çalışmada da ortaya konmuş olmakla birlikte, yukarıda önerildiği şekilde medyada doğru kanaldan, doğru bilgiler verilmediği ve bu bilgiler denetlenmediği takdirde, diyabetli bireylerin beslenme ve sağlik durumları ve hastalık seyri bozulabilir. Hâlbuki bu bireylerin besin tüketim tercihlerinin tıbbi beslenme tedavilerine uyumlu olması gerekmektedir. $\mathrm{Bu}$ nedenle tedavi süreci devam eden bu hastalar ve diyetisyenler iletişim halinde olmalı, hastalar beslenmede değişiklik yaparken sağlık profesyonellerine danışmalıdır. Fakat hastaların büyük çoğunluğunun medyadan aldıkları bilgileri diyetisyene/doktora sormadığı belirlenmiştir (Tablo 3). Medyada beslenme alanında yetkin uzmanların bilgi vermesi devlet otoritelerince teşvik edilmeli, bu yönde denetlemeler yapılmalıdır. Böylece medyada yer alan bilgilerin diyetisyene/doktora danışılması gerektiği mesajı da verilebilir.

Tip 2 DM hastalarında bilgi düzeyi arttıkça hastaların daha sağlıklı beslendiği gösterilmiştir [27]. Bu çalışmada DM hastalarının diyabette beslenme bilgi düzeyi anketindeki doğru cevap ortalaması (beslenme bilgi düzeyi puanı) $13.48 \pm 2.44$ (13.00/20 puan) olarak bulunmuştur. Bireylerin 20 sorunun yaklaş1k 13'üne doğru cevap verdiği görülmektedir. Ankara'da DM okuluna devam eden Tip 2 DM'li hastaların DM bilgi testindeki sorulara benzer oranda doğru cevap verdikleri belirlenmiştir [28]. Diyabetli hastaların beslenme bilgi puanına göre yarısından fazlasının orta ve yeterli bilgi düzeyine sahip oldukları başka bir çalışmada da bildirilmiştir [29]. Kronik bir hastalık olan DM yönetiminde hastaların hekim ve diyetisyen tarafindan düzenli takip edilmelerinin diyabette beslenme bilgi düzeylerinin artmasında etkisi olduğu düşünülmektedir. $\mathrm{Bu}$ çalışmada hastaların diyabette beslenme bilgi düzeyleri; cinsiyetler arasında farklılık göstermezken, medyay1 takip eden ve etmeyen, medyada yer alan bilgilendirici içeriklerin besin seçimini etkilediğini düşünen ve düşünmeyen, medyadaki beslenme içeriklerini takip eden ve etmeyen hastaların diyabette beslenme bilgi düzeyleri benzerdir (Tablo 4). Bu sonuçlar hastaların büyük çoğunluğunun, diyetisyen tarafından diyabet hastalığına yönelik beslenme eğitimi almış olmaları ile açıklanabilir (Tablo 1). Öte yandan diyabette beslenme bilgi düzeyi, eğitim düzeylerine göre farklılık göstermektedir. İlkokul mezunu olan hastaların bilgi düzeyi en düşük iken, lise mezunu olanların en yüksektir (Tablo 4). Bu bulgular, önceki çalışmaların sonuçlarıyla paralellik göstermektedir [5, 29].

Diyabette beslenme bilgi düzeyi, besin etiketi okuyan bireylerde, okumayanlara göre yüksek bulunmuştur $(p=0.016)$. Besin etiketi okuyan bireylerin, ürünlerin içindekileri, enerji ve besin ögesi değerlerini ve şeker içeriğini okumaları ve besin seçiminde sağlığa uygunluğa dikkat etmeleri (Tablo 2); enerji ve besin ögesi gereksinimlerini ve besinlerin hangi besin ögeleri için kaynak olabileceğini öğrenmelerini sağlamış, onları doğru besin seçimine yönlendirmiş, ve bu süreç beslenme bilgisine katkı yapmış olabilir. Zira besin etiketi okumanın beslenme bilgisini arttırdığı [30], sağlıklı besin seçimine yönlendirdiği [31] ve besin etiketi okuyan bireylerin sağlıklı besinleri tanıma yeteneklerinin $\operatorname{arttığ} 1$ [32] bilinmektedir.

Diyabetli hastaların tedavisinde iyi glisemik kontrol ve multifaktöriyel riski azaltmak hedeflenmektedir. HbA1c son 8-12 haftalık dönemdeki glisemik kontrolün iyi bir göstergesidir [29]. Diyabet hastalarında tıbbi beslenme tedavisi hakkındaki bilgi düzeyinin metabolik kontrolü olumlu yönde etkilediği belirtilmektedir [29, 33]. Bu çalışmada diyabette beslenme bilgi düzeyi ile açlık kan glukozu, HbA1c, trigliserit, total kolesterol, HDL-K, LDL-K arasında ilişki saptanmamıştır (Tablo 5). Benzer şekilde Özdemir ve arkadaşlarının [29] yaptıkları çalışmada da diyabetli hastaların beslenme bilgi puanı ve $\mathrm{HbA1c}$ değerleri arasında istatistiksel olarak önemli ilişki bulunmamıştır. Diyabetin metabolik kontrol bileşenleri hastaların beslenme alışkanlıkları, egzersiz davranışları, ilaç tedavileri gibi birçok faktörden etkilenmektedir. Bu nedenle, kesitsel olan bu çalışmanın veri toplama sürecinde; beslenme bilgi düzeyinin, hastaların biyokimyasal bulgularına direkt etkili olmadığı düşünülmektedir.

Bu kesitsel çalışmada ulaşılabilen örneklem hacmi, elde edilen bulguların tüm diyabetli hasta popülasyonunda yorumlanmasını güçleştirmektedir. Ancak, elde edilen sonuçlarla diyabette beslenme eğitimlerinde besin etiketleri ile ilgili daha fazla bilgi verilmesinin; hastaların beslenme bilgi düzeyine olumlu etkisi olabileceği önerilmiştir.

\section{Sonuç}

Sonuç olarak diyabet hastaları televizyon, sosyal medya gibi kitle iletişim araçlarını yaygın kullanmakta olup, hastalar en çok sağlıklı beslenme konularını takip etmektedir. Hastalar, medyanın beslenme ile ilgili bilgi düzeylerini arttırdığını düşünmelerine rağmen, beslenme bilgi düzeyleri ile medyayı takip etme durumları arasında ilişki saptanmamıştır. Medyanın diyabetli hastaların besin seçimi ve beslenme alışkanlıkları üzerinde ne gibi etkileri olduğunun anlaşılabilmesi için daha çok çalışmaya ihtiyaç vardır. Diyabetli hastaların medya araçlarından diyabette beslenme bilgi düzeylerini arttıracak şekilde yararlanmaları için stratejiler geliştirilmelidir.

\section{Referanslar}

1. Türkiye Endokrinoloji ve Metabolizma Derneği (TEMD), Diabetes Mellitus ve Komplikasyonlarının Tanı, Tedavi ve İzlem Kılavuzu2019

http://temd.org.tr/admin/uploads/tbl_kilavuz/20190819095854-

2019tbl_kilavuzb48da47363.pdf (Erişim Tarihi:10.07.2020).

2. Satman, İ, Alagöl, F, Ömer, B, Kalaca, S, Tütüncü, Y, Çolak, N, Türkiye Diyabet, Hipertansiyon, Obezite ve Endokrinolojik Hastalıklar Prevalans Çalışması-II, (TURDEP II), 2011.

3. Tuomilehto, J, Lindström, J, Eriksson, J.G, Valle, T, T, Hämäläinen, $\mathrm{H}$, Ilanne-Parikka, et al., Prevention of type 2 diabetes mellitus by changes in lifestyle among subjects with impaired glucose tolerance, New England Journal of Medicine, 2001, 344(18), 1343-1350. 
4.Woo, Y.J, Lee, H.S, Kım, W.Y, Individual Diabetes Nutrition Education Can Help Management For Type II Diabetes, Journal Of Nutrition And Health, 2006, 39(7), 641-648.

5. Al Bimani, Z.S, Khan, S.A, David, P, Evaluation Of T2DM Related Knowledge And Practices of Omani Patients, Saudi Pharmaceutical Journal, 2015, 23(1), 22-27.

6. Aktaş, N, Cebirbay, M.A, Tüketicilerin Beslenme Bilgilerine Erișmede Kullandıkları Kitle İletișim Araçları Üzerine Bir Araştırma. Karadeniz Uluslararası Bilimsel Dergi, 2011, 11, 47-56.

7. Tuna Oran, N, Toz, H, Küçük, T, Uçar, V, Medyanın Kadınların Beslenme Alıșkanlıkları, Besin Seçimi Ve Tüketimi Üzerindek Etkileri, Life Sciences, 2017, 12(1), 1-13.

8. Bulduklu, Y, Televizyonda Yayınlanan Sağlık Programlarıve İzleyicileri, Selçuk Üniversitesi Sosyal Bilimler Enstitüsü Dergisi, 2010, 24, 75-85.

9. Boyland, E.J, Halford, J.C, Television Advertising And Branding, Effects On Eating Behaviour And Food Preferences in Children Appetite, 2013, 62, 236-241.

10. Acar Tek, N, Yurtdaş, G, Beslenme Alışkanlıklarını/Diye Örüntüsünü Etkileyen Çevresel Etmenler, Hedef Yayıncılık, 2019

11. Şahin, H, Yılmaz M, Ongan D, Çiçek B, Budak N, İnanç N, Tip 2 Diyabetli Bireylere Verilen Beslenme Eğitiminin Beslenme Bilg Düzeyi Üzerine Etkisi, VIII. Uluslararası Beslenme ve Diyetetik Kongresi, Poster Bildiri, Antalya, 2012, Sayfa:333,

12. Serrano-Gil, M, Jacob, S, Engaging And Empowering Patients to Manage Their Type 2 Diabetes, Part I: A Knowledge, Attitude, and Practice Gap? Advances İn Therapy, 2010, 27(6), 321-333.

13. Dilber, F, Dilber, A, Üniversite Öğrencilerinin Gıda Ürünler Tüketiminde Medyanın Etkisi: Karamanoğlu Mehmet Bey Üniversitesi Öğrencileri Üzerine Bir Araştırma, Gümüşhane Üniversitesi Illetișim Fakültesi Elektronik Dergisi, 2013, 2(1), 67-82.

14. Keser, A, Çıracıŏlu, E.D, Sağlık ve Beslenme Okuryazarlığ 1 . Yıldırım, F ve Keser, A. (Ed.), Sağlık Okuryazarlığı, Ankara Üniversitesi Yayın No:455, Ankara Üniversitesi Basımevi, Ankara, 2015, 39-59.

15. Coskun, F, Kayıssoğlu, S, Besin Etiketi Okuma Alıskanlıklarına ve Etiket Okumanın Satın Alma Tercihlerine Cinsiyetin Etkisi: Tekirdağ İli Örneği, Akademik GIDA, 2018, 16(4).

16. Aygen, F.G, Attitudes And Behavior Of Consumers Related To The Inspection Of Food Labels, Journal Business Research Turk, 2012, 4(3), 28-54.

17. Nieto, C, Tolentino-Mayo, L, Monterrubio-Flores, E, Medina, C, Patiño, S. R. G, Aguirre-Hernández, R, Barquera, S, Nutrition Label Use is Related to Chronic Conditions Among Mexicans: Data From The Mexican National Health And Nutrition Survey 2016, Journal Of The Academy Of Nutrition And Dietetics, 2020, 120(5), 804-814.

18. Aygen, F.G, Tüketicilerin Besin Etiketi İncelenmesi Konusundaki Tutum ve Davranışları, İşletme Araştırmaları Dergisi, 2012, 4(3), 28 54

19. Gözener, B, Büyükbay, E.O, Sayılı, M, Gıda Güvenliği Konusunda Öğrencilerin Bilgi Düzeylerinin İncelenmesi, Gaziosmanpaşa Üniversitesi Ziraat Fakültesi Dergisi, 2009, 26 (2), 45-53

20. Mutlu, E, Medya Araçlarının Başkent Üniversitesi Öğrencilerinin Beslenme Davranışları ve Gıda Ürünlerinin Seçiminde Karar Vermedeki Etkisi, Halk Sağlığı Ana Bilim Dalı, Yüksek Lisans Tezi, Ankara, 2018.

21. Abedin, T, Al Mamun, M, Lasker, M.A, Ahmed, S.W, Shommu, N, Rumana, N, Turin, T.C, Social Media As A Platform For İnformation About Diabetes Foot Care: A Study Of Facebook Groups, Canadian Journal Of Diabetes, 2017, 41(1), 97-101.

22. Aktas Arnas, Y, The Effects Of Television Food Advertisement On Children's Food Purchasing Requests, Pediatrics International, 2006 48(2), 138-145

23. Arslan, A, Türkiye'de Medya-Toplum İlişkisi ve Medyanın Profesyonellik Etiği Üzerine Sosyolojik Bir Değerlendirme: Akademik Bakıș, Uluslararası Hakemli Sosyal Bilimler E-Dergisi, 2005, 5(1), 1-13

24. Yıldıran, H, Çelik, E, Karadağ, M, Üniversite Öğrencilerinde Medyanın Besin Seçimi ve Beslenme Alıșkanlıkları Üzerine Etkisi, Hacettepe Üniversitesi Sağllk Bilimleri Fakültesi Dergisi, 2016, 3(1), 96

25. Mankan, E, İçer, D. Beslenme-Gastronomi ile İlgili Haberlerin ve Köșe Yazılarının Üniversite Öğrencilerinin Beslenme
Alışkanlıklarına Etkisi, Social Sciences Studies Journal (Sssjournal), 2017, 3(8),558-566

26. Aksoydan, E, Kartal, B, Yılmaz, K, Medya Kadınları Beslenme Konusunda Nasıl Etkiliyor? Sürekli Tip Eğitim Dergisi: STED, 2010 19(1), 1-5.

27. Fitzgerald, N, Damio, G, Segura-Pérez, S, \& Pérez-Escamilla, R, Nutrition Knowledge, Food Label Use, And Food İntake Patterns Among Latinas With And Without Type 2 Diabetes, Journal Of The American Dietetic Association, 2008, 108(6), 960-967.

28. Mançu Tülek, T, Ankara'da Diyabet Okuluna Devam Eden Tip 2 Diyabetli Yetişkin Bireylerin Beslenme Bilgi Düzeylerinin ve Diyabet Tutumlarının Değerlendirilmesi, Sağlık Bilimleri Enstitüsü, Yüksek Lisans Tezi, Ankara, 2018.

29. Özdemir, M, Aksoydan, E, Çakır, R.E, Coşkun, Y, Kocamış, R.N, Başkent Üniversitesi Sağllk Bilimleri Fakültesi Dergisi-BÜSBİD, 2016, 1(2).

30. Cavaliere, A, Siletti, E, Banterle, A, Nutrition İnformation, Mediterranean Diet, And Weight: A Structural Equation Approach, Agricultural Economics, 2020, 66(1), 10-18.

31. Ramdan, M.R, Zainol, Z, Yahaya, R, Habidin, N.F, Osman, J, The Effect Of Nutrition Label Literacy And Attitude Towards Nutrition Label On Healthy Food Choice Among Consumer In Malaysia, International Journal Of Academic Research In Business And Social Sciences, 2018, 8(2), 671-686.

32. Egnell, M, Ducrot, P, Touvier, M, Allès, B, Hercberg, S, KesseGuyot, E, et al., Objective Understanding Of Nutri-Score Front-OfPackage Nutrition Label According To İndividual Characteristics Of Subjects: Comparisons With Other Format Labels, Plos One, 2018 , 13(8), 20-95.

33. Gunggu, A, Thon, C.C, Lian, C.W, Predictors Of Self-Management Behaviors Among Type 2 Diabetes Patients, Journal of Diabetes Research, 2016, 2, 2270-4.

http://edergi.cbu.edu.tr/ojs/index.php/cbusbed isimli yazarın CBU-SBED başlıklı eseri bu Creative Commons Alınt1-Gayriticari4.0 Uluslararası Lisansı ile lisanslanmıștır.

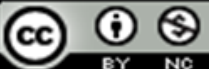

